Review Article

\title{
Catunaregam spinosa (Thunb.) Tirveng: A Review of Traditional Uses, Phytochemistry, Pharmacological Activities, and Toxicological Aspects
}

\author{
Deepak Timalsina $\left(\mathbb{D},{ }^{1}\right.$ Hari Prasad Devkota $\left(\mathbb{D},{ }^{2,3}\right.$ Deepti Bhusal ${ }^{\mathbb{D}},{ }^{1}$ \\ and Khaga Raj Sharma $\mathbb{B D}^{1}$ \\ ${ }^{1}$ Central Department of Chemistry, Tribhuvan University, Kirtipur, Kathmandu 44618, Nepal \\ ${ }^{2}$ Graduate School of Pharmaceutical Sciences, Kumamoto University, 5-1 Oe-honmachi, Chuo-Ku, Kumamoto 862-0973, Japan \\ ${ }^{3}$ Program for Leading Graduate Schools, HIGO Program, Kumamoto University, 5-1 Oe-honmachi, Chuo-Ku, \\ Kumamoto 862-0973, Japan
}

Correspondence should be addressed to DeepakTimalsina; geniusdipu5@gmail.com and Khaga RajSharma; khagaraj_sharma33@ yahoo.com

Received 16 April 2021; Accepted 17 August 2021; Published 26 August 2021

Academic Editor: Amjad Iqbal

Copyright (C) 2021 Deepak Timalsina et al. This is an open access article distributed under the Creative Commons Attribution License, which permits unrestricted use, distribution, and reproduction in any medium, provided the original work is properly cited.

\begin{abstract}
Catunaregam spinosa (Thunb.) Tirveng. (Syn. Randia dumetorum (Retz.) Lam.), belonging to the Rubiaceae family, is distributed in south Asian countries. It is used as a traditional medicine to treat gastrointestinal and hepatic problems and as an antiinflammatory and antimicrobial agent. The main aim of this review is to collect and analyze the available scientific information on traditional uses, phytochemistry, and pharmacological activities of C. spinosa. The scientific information related to C. spinosa was collected from various resources and databases such as SciFinder, Scopus, PubMed, and other databases. C. spinosa was found to be an important crude drug of the traditional medicinal systems such as Ayurveda. It was found to be used by the people of India as an alternative medicine, while the fruit of this plant was found to be used in dietary regimens as well. Active phytochemicals such as catunarosides, randianin, and several other saponins and triterpenoids possess various pharmacological activities such as antiinflammatory, hepatoprotective, antibacterial, and immunomodulatory activities. Many studies have been performed to isolate the active compounds; however, there is a need for more activity-guided isolation studies. Various in vitro studies showed promising results but there are not many studies related to mechanism of actions using animal models. Hence, future studies on C. spinosa should focus on correlating the traditional uses with active phytoconstituents and modern pharmacological activities.
\end{abstract}

\section{Introduction}

Humans have been dependent on plants since the ancient times for various reasons such as food, shelter, and medicine [1]. Medicinal plants are the primary source of health benefits in various communities of the world [2]. More than $80 \%$ of the world's population is reported to use plant-based medicines as primary healthcare as they are easily available and safe to use [3]. Recently, researchers have developed traditional knowledge about medicinal plants which can fulfill the current gap in therapeutics, nutraceuticals, drug discovery, and development [4]. Especially in developing countries, the reliance on plant medicine is a typical basis for addressing the ethnomedicinal knowledge in therapeutics from different ethnic communities [5].

Altogether 68 names of species are recorded under the genus Catunaregam belonging to family Rubiaceae [6]. The particular species Catunaregam spinosa (Thunb.) Tirveng. (Figure 1) is a shrub with thorns which is distributed up to $4000 \mathrm{ft}$. from the sea level [7]. The other synonyms of this species are given in Table 1 [6]. C. spinosa, known as Madana in Sanskrit, Madanphal in Nepali, and emetic nut or mountain pomegranate in English, is a deciduous shrub with approx. $5 \mathrm{~m}$ of height, leaves are ovate, simple, shiny, and 

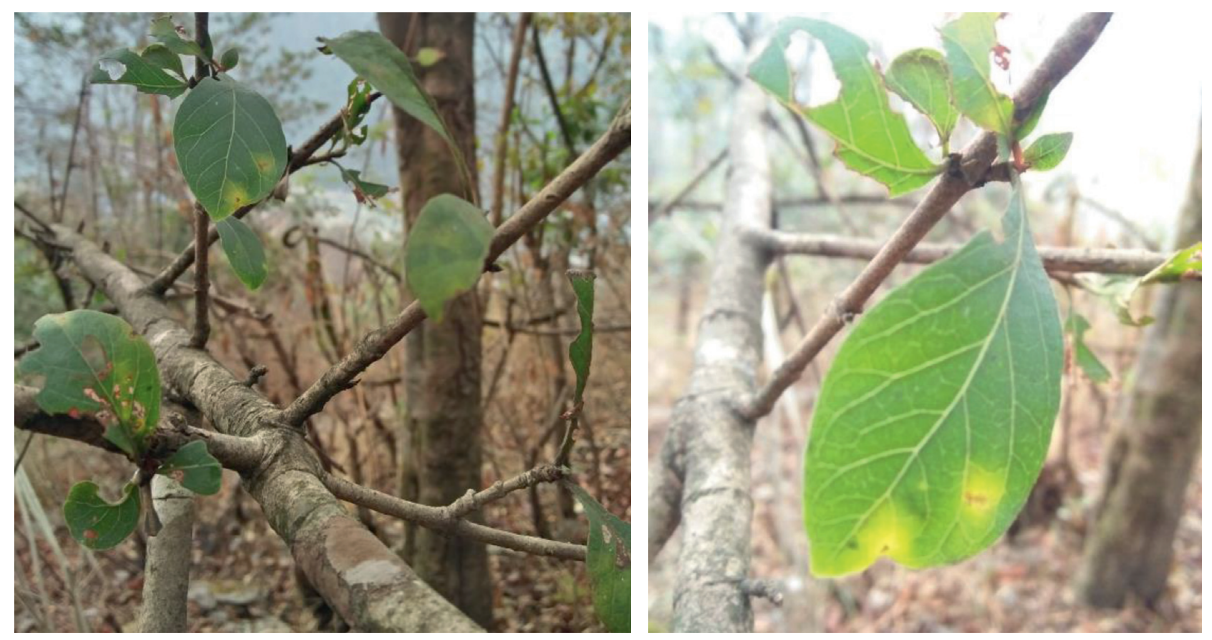

Figure 1: Photographs of Catunaregam spinosa (Thunb.) Tirveng.

TABle 1: Synonyms of C. spinosa [6].

Canthium chinense Pers.

Canthium coronatum Lam.

Ceriscus malabaricus Gaertn.

Gardenia dumetorum Retz.

Gardenia dumosa Salisb.

Gardenia spinosa Thunb.

Gardenia stipularis Rottler

Genipa dumetorum (Retz.) Baill.

Narega coduva Raf.

Posoqueria dumetorum (Retz.) Willd. ex Roxb.

Posoqueria floribunda Roxb.

Randia floribunda (Roxb.) DC.

Randia lachnosiphonium Hochst.

Randia oxypetala Lindl.

Randia rottleri Wight \& Arn.

Randia spinosa (Thunb.) Poir.

Randia stipulosa Miq.

Randia tomentosa Wight \& Arn.

Randia uniflora Regel

Solena dumetorum (Retz.) D.Dietr.

Solena floribunda (Roxb.) D.Dietr.

Solena longispina D.Dietr.

Solena nutans D.Dietr.

Xeromphis retzii Raf.

pubescent [8], and flowers are white solitary and possess a honey-like fragrance [9]. This plant has been reported from various parts of India [10], Nepal, Bangladesh, South China [11], and the African subcontinent [12]. C. spinosa is reported to be distributed in tidelands of semitropical and subtropical areas [13]. The ancient medicinal systems of Ayurveda and Siddha use this plant to treat various types of symptoms and it is still in use [14]. "Rasayana," a kind of clinical specialties in Ayurveda, uses this plant for promoting good habits in the dietary regimen [15]. People in India and Brazil use this plant for treating food poisoning, inducing vomiting, and treating allergy and inflammation [16]. The presence of various important phytoconstituents such as phenols, flavonoids [17], triterpene saponins [18, 19], hemolytic saponins, randianin [20], iridoids [21], dihydroisocoumarin [13], and many more other phytoconstituents is reported from various parts. Several studies have reported the modern pharmaceutical activities of C. spinosa such as piscicidal [22], molluscicidal [23], antioxidant [8], anti-inflammatory, antidiabetic, and antihyperlipidemic [24] activities. The isolated compounds are not well studied for the possibility of drug discovery pathways. It is important to have a clear idea of this medicinally important plant and its scientific progress. The review of the current state of C. spinosa and its overall perspective related to ethnomedicinal importance and modern medicine is still lacking. Thus, this review aims to collect and analyze the current status of traditional uses, phytochemicals, and pharmacological activities from the available scientific information.

\section{Methodology}

The scientific information of C. spinosa was collected from various online databases such as SciFinder, Scopus, Google Scholar, PubMed, Web of Science, and ScienceDirect. Additionally, the books, proceedings, comments, and editorials were used as secondary sources. The scientific names and their synonyms were cross-checked from the database available in the website of "The Plant List" (http://www. theplantlist.org/). The articles of better quality with sufficient taxonomical, ethnomedicinal, and pharmacological information were selected while preparing this review.

\section{Traditional Uses in Medicine and Food}

The fruit of C. spinosa is traditionally used to treat various symptoms (Table 2). Almost all parts of the plant have been used as a traditional medicine in Ayurveda and fruits have been reported to be used in medicine as well as in food. This plant is reported to treat ulcers, inflammation, tumors, wounds, and skin diseases [7]. People from the upper hilly region of India used its bark for curing diarrhea and dysentery [25]. The fruits or pulps of this plant are used as an abortifacient [26] and nauseant [11], as well as for treating asthma [27, 28]. The fruit of C. spinosa is also taken as a nutrient or diet. 
TABle 2: The traditional uses of C. spinosa in medicine and food.

\begin{tabular}{|c|c|c|c|}
\hline $\begin{array}{l}\text { Country (locality if } \\
\text { available) }\end{array}$ & Plant parts & Uses & References \\
\hline Bangladesh & Fruits & Taken as a juice for treating anthelmintic, tonic, and curing piles, flatulence & {$[12,29]$} \\
\hline Bangladesh, (Bagerhat) & All parts & $\begin{array}{c}\text { Taken in the form of juice for treating urinary tract infections and genital } \\
\text { disorder }\end{array}$ & {$[30]$} \\
\hline Brazil & All parts & Taken as a crushed paste for treating dysentery and inflammations & [13] \\
\hline China (Hainan) & Stem bark & Taken in the form of paste to prevent the growth of cancer & {$[31]$} \\
\hline India & Barks & Crushed bark juice is taken to treat diarrhea and dysentery & {$[25]$} \\
\hline India & All parts & $\begin{array}{l}\text { Taken in the form of juice in an empty stomach for improving the defense } \\
\text { mechanism of the body and improving longevity }\end{array}$ & {$[32]$} \\
\hline India & Leaves & Used in the form of a solution and is useful in controlling Molluscans & {$[23]$} \\
\hline India (Assam, Manipur) & All parts & Taken in the form of juice for treating liver ailments & {$[17]$} \\
\hline $\begin{array}{l}\text { India (Kalakkad, Tamil } \\
\text { Nadu) }\end{array}$ & $\begin{array}{l}\text { Root bark and } \\
\text { stem bark }\end{array}$ & $\begin{array}{c}\text { Taken in the form of juice in an empty stomach for treating constipation, fever, } \\
\text { and an antiseptic }\end{array}$ & {$[33]$} \\
\hline India (Karnataka) & All parts & Apply in the form of paste as well as juice for treating various skin diseases & {$[34]$} \\
\hline India (Kedarnath) & Fruits & $\begin{array}{c}\text { Apply in the form of paste for treating skin disease, in the form of juice for } \\
\text { ulcers, abortifacient, cough, rheumatism, and fever }\end{array}$ & {$[26,35]$} \\
\hline India (Kerala) & Seeds & The solution of crushed seeds in water is used in controlling mosquito larva & {$[36]$} \\
\hline $\begin{array}{l}\text { India (Kolli and Boda } \\
\text { hills) }\end{array}$ & Fruits & Taken as a vegetable for vitamin and mineral content, nutritional diet & [37] \\
\hline India (Nasik) & Flowers & Taken as vegetable for improving dietary habits & [38] \\
\hline India (Pune, Goa) & Fruits & $\begin{array}{c}\text { Taken in the form of juice in treating gonorrhea, asthma, tonic, emetic, } \\
\text { jaundice, dysentery }\end{array}$ & {$[27,39]$} \\
\hline $\begin{array}{l}\text { India (Sikkim, Bengal, } \\
\text { Maharashtra) }\end{array}$ & Fruits & $\begin{array}{c}\text { Applied in the form of paste in treating allergy, wound infections, and skin } \\
\text { diseases }\end{array}$ & {$[10]$} \\
\hline India (Western Ghats) & & Taken as a juice for treating rheumatism, diarrhea, and viral diseases & {$[40]$} \\
\hline Nepal (Chitwan) & Ripen fruits & Crushed seed and its solution is effective in treating fish poison & {$[22]$} \\
\hline Sri Lanka & Bark and leaves & Apply in the form of paste for curing skeletal fractures & [41] \\
\hline
\end{tabular}

\section{Chemical Constituents}

Various flavonoids, alkaloids, tannins, lignans, terpenoids, and volatile oils have been reported from this plant. The triterpene, saponins [21], and iridoid glucosides were isolated [42] from the fruits of C. spinosa. Three triterpenoid saponins, $\quad 3-\mathrm{O}-[\beta$-D-glucopyranosyl- $(1 \longrightarrow 3)-\beta-\mathrm{D}-6-\mathrm{O}-$ methyl-glucuronopyranosyl oxy]-2 $\beta$-hydroxy-olean-12-en28 -oic acid, 3-O-[ $\beta$-D-glucopyranosyl- $(1 \longrightarrow 2)-\beta$-D-glucopyranosyl]-olean-12-en-28-oic acid, and 3-O-[ $\beta$-L-rhamnopyranosyl-(1 $\longrightarrow 3)-\beta$-D-glucuronopyranosyl- $(1 \longrightarrow 2)$ $\beta$-D-glucopyranosyl-(1-2)- $\beta$-D-glucopyranosyl]-12-en28 -oic acid, and two triterpenoids, oleanolic acid and $3 \beta, 23$ dihydroxy-olean-12-ene-28-oic acid, were isolated from fruits [43]. From the stem bark of C. spinosa, the compounds named catunaregin and epicatunaregin were isolated [44]. Many triterpenoid saponins such as catunarosides were reported [45] from the $\mathrm{n}-\mathrm{BuOH}$ extract of the stem bark of this plant. There have also been studies on nutritional contents of the fresh fruit of this plant and they were reported to contain a high amount of carbohydrate [38]. 11Methylixoside was isolated from the bark of C. spinosa [46]. The bioactive compounds are enlisted in Table 3 and their structures are in Figures 2-6.

\section{Pharmacological Activities}

Due to the widespread traditional uses, C. spinosa extracts and compounds have been subjected to various pharmacological activity evaluations. This plant has been studied widely for its pharmacological activities, mainly antibacterial, antioxidant, anti-inflammatory, antimicrobial, anticancer, and antifertility activities. Few studies have reported sedative and analgesic activities. Most of the activities are based on random screening rather than traditional knowledge, which cannot provide the correlation between ethnomedicine and modern pharmacological activities. Some studies carried out on C. spinosa are discussed in the following section.

5.1. Antimicrobial Activities. The extract obtained from the fruit bark of $C$. spinosa showed prominent antibacterial activity against various species of Proteus, Staphylococcus, Clostridium, Salmonella, Vibrio, Bacillus, Escherichia, and Pseudomonas [53].

The water extract of the seed of C. spinosa was tested against human pathogenic bacteria such as Staphylococcus aureus, Bacillus subtilis, Escherichia coli, Klebsiella pneumonia, and Proteus mirabilis; and the minimum inhibitory concentration (MIC) was found to be $0.07,0.08,0.88,3$, and $0.73 \mathrm{mg} / \mathrm{mL}$, respectively, and the zone of inhibition ranged from 15 to $20 \mathrm{~mm}$ [36].

In another study, the antimicrobial activity was performed by the broth dilution method and disc diffusion method against various Gram-positive and Gram-negative bacteria. The methanolic extract of leaves of C. spinosa showed a potent effect against Gram-negative bacteria, that is, K. pneumoniae, E. coli, and S. typhi, as compared to Gram-positive bacteria, that is, B. subtilis and S. aureus [40]. 
TABle 3: Bioactive compounds reported from C. spinosa.

\begin{tabular}{lccc}
\hline Chemical class & Compounds & $\begin{array}{c}\text { Plant } \\
\text { parts }\end{array}$ & References \\
\hline Lignans & $\begin{array}{c}\text { Catunaregin, epicatunaregin, balanophonin, ficusal, 5"-methoxy-4" }- \\
\text { O-(8- guaiacylglycerol)buddlenol A, pinoresinol, medioresinol, } \\
\text { secoisolariciresinol }\end{array}$ & $\begin{array}{c}\text { Stem } \\
\text { bark }\end{array}$ & $\begin{array}{l}{[13,31,44]} \\
\text { Coumarins and isocoumarin }\end{array}$ \\
\hline
\end{tabular}

Catunaroside A, catunaroside $\mathrm{B}$, catunaroside $\mathrm{C}$, catunaroside $\mathrm{D}$, catunaroside $\mathrm{E}$, catunaroside $\mathrm{F}$, catunaroside $\mathrm{G}$, catunaroside $\mathrm{H}$, catunaroside I, catunaroside J, catunaroside $\mathrm{K}$, catunaroside $\mathrm{L}$, Arjunetoside, Randiasaponin IV, swartziatrioside, araliasaponin V, araliasaponin IV, mussaendoside J, daucosterol, $\beta$-sitosterol, lupeol, 1 keto-3-hydroxyoleanane, randialic acid $\mathrm{B}$

Urosaponin, dumetorinins A-F, randianin, 3-O- $\beta$-D-glucopyranosyl$(1 \longrightarrow 3)-\beta$-D-6-O-methyl-glucuronopyranosyl oxy]-2 $\beta$-hydroxyolean-12-en-28-oic acid, 3-O-[ $\beta$-D-glucopyranosyl- $(1 \longrightarrow 2)-\beta$-Dglucopyranosyl]-olean-12-en-28-oic acid, 3-O-[ $\beta$-L-

Steroids, triterpenoids, and their glycosides (saponins) rhamnopyranosyl- $(1 \longrightarrow 3)-\beta$-d-glucuronopyranosyl- $(1 \longrightarrow 2)-\beta$-D-

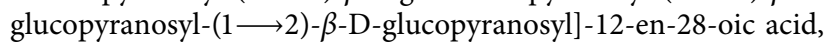
$3 \beta, 23$-dihydroxy-olean-12-ene-28-oic acid and olenolic acid, 3-O-[O$\beta$-D-glucopyranosyl- $(1 \longrightarrow 4)-\mathrm{O}-\beta$-D-glucopyranosyl- $(1 \longrightarrow 3)-(\beta$-Dglucuronopyranosyl)] oleanolic acid, 3-O-[O- $\beta$-D-glucopyranosyl$(1 \longrightarrow 6)-\mathrm{O}-\beta$-D-glucopyranosyl-( $1 \longrightarrow 3)-(\beta$-D-glucuronopyranosyl)] oleanolic acid, randioside $A$

1-Keto- $3 \alpha$-hydroxyoleanane, $\alpha$-amyrin, $\beta$-amyrin
Fruits $[9,18,20,43,51,52]$
Stem
bark $[9,13,19,45,47-50]$

(1)

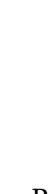

\begin{tabular}{|c|c|c|c|}
\hline & 1-Keto- $3 \alpha$-hydroxyoleanane, $\alpha$-amyrin, $\beta$-amyrin & $\begin{array}{l}\text { Root } \\
\text { bark }\end{array}$ & [19] \\
\hline \multirow[b]{2}{*}{ Iridoids } & 11-Methylioxiside & Leaves & {$[9,21,46]$} \\
\hline & 3-Deoxyartselaenin C, morindolide & $\begin{array}{l}\text { Stem } \\
\text { bark }\end{array}$ & [13] \\
\hline
\end{tabular}

The fruit extract of C. spinosa was subjected to its antimicrobial activity by the disc diffusion method, where it was tested against $P$. aeruginosa, E. coli, S. pyogenes, S. typhi, $S$. pyogenes, and B. subtilis. The activity of the extract was tested as compared to the standard Chloramphenicol. One hundred $\mu \mathrm{g} / \mathrm{mL}$ of the ethanolic extract showed more potency and highest zone of inhibition of $28.0 \mathrm{~mm}$ against the Bacillus and Klebsiella pneumoniae of $24.0 \mathrm{~mm}$ and the lowest was that of Streptococcus pyogenes. In chloroform extract, the maximum zone of inhibition of $26 \mathrm{~mm}$ was recorded for Bacillus subtilis followed by Pseudomonas aeruginosa of $16 \mathrm{~mm}$ and it was lower for the remaining bacteria. In the aqueous extract, the maximum zone of inhibition of $18 \mathrm{~mm}$ was recorded for Klebsiella pneumonia followed by Bacillus subtilis of $14.0 \mathrm{~mm}$ and it was lower for other bacteria [54].

5.2. Hepatoprotective Activities. The hepatoprotective potential of methanolic extract of the fruit of C. spinosa at the dose of $200 \mathrm{mg} / \mathrm{kg}$ was studied in male albino Wistar rats with alcohol (28.5\%) induced liver injury. The biochemical parameter and histopathology of the liver were accessed before and after treatment and were found to be significant to retrieve the parameters towards the normal stage. The treatment with standard silymarin and C. spinosa extract showed a decrease in the elevated levels of alanine aminotransferase (ALT), aspartate aminotransferase (AST), direct bilirubin (DB), and triglyceride (TG) as compared to rats exposed to alcohol only. The histopathological examination showed severe necrosis in cells treated with alcohol only, while reduced necrosis was found in the rats treated with C. spinosa extracts [55].

A similar study was performed in carbon tetrachloride $\left(\mathrm{CCl}_{4}\right)$ induced hepatic damaged rats [17]. The animal treated with C. spinosa leaf and bark extracts at $400 \mathrm{mg} / \mathrm{kg}$ for 15 days showed a significant decrease in various biochemical parameters such as ALP, AST, ALT, LDH, albumin, and total and direct bilirubin and an increase in total protein levels as compared to the $\mathrm{CCl}_{4}$ only treated group.

However, in these studies, the mechanism by which C. spinosa is protecting liver injury is yet to be studied. Further, the studies on the isolation and identification of active compounds and elucidation of their mechanism of action are necessary.

5.3. Antioxidant Activities. Methanolic extracts obtained from the fruit bark of $C$. spinosa were studied for their antioxidant activities. The DPPH radical scavenging assay, nitric-oxide scavenging assay, and superoxide inhibition assay were done for which the value was expressed in $\mathrm{EC}_{50}$. The $\mathrm{EC}_{50}$ value for the DPPH assay for the extract was $37 \mu \mathrm{g} /$ $\mathrm{mL}$, whereas the $\mathrm{EC}_{50}$ value for standard (pyrogallol) was $1.7 \mu \mathrm{g} / \mathrm{mL}$. The $\mathrm{EC}_{50}$ value of the extract for nitric-oxide scavenging assay was $16.8 \mu \mathrm{g} / \mathrm{mL}$ as compared to the 

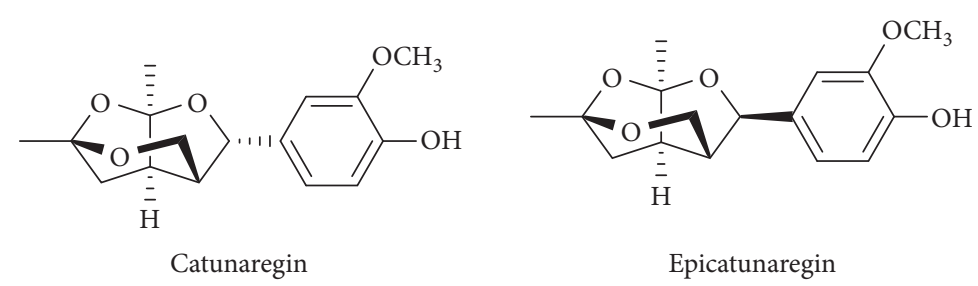<smiles>COc1cc([C@@H]2Oc3c(OC)cc(/C=C/C=O)cc3[C@H]2CO)ccc1O</smiles><smiles>COc1cc([C@H]2Oc3c(OC)cc(C=O)cc3[C@@H]2CO)ccc1O</smiles>

Ficusal<smiles>COc1cc(C(O)C(CO)Oc2c(OC)cc(C3Oc4c(OC)cc(/C=C/C=O)cc4C3CO)cc2OC)ccc1O</smiles>

Buddlenol A<smiles>COc1cc([C@@H]2OC[C@]3(C)[C@@H](c4ccc(O)c(OC)c4)OC[C@]23C)ccc1O</smiles>

Pinoresinol<smiles>COc1cc([C@@H]2OC[C@@]3(C)[C@@H](c4cc(OC)c(O)c(OC)c4)OC[C@]23C)ccc1O</smiles>

Medioresinol<smiles>COc1cc(C[C@H](CO)[C@H](CO)Cc2ccc(O)c(OC)c2)ccc1O</smiles>

Secoisolaricoresinol

FIGURE 2: Structures of lignans.<smiles>COc1cc2ccc(=O)oc2cc1O</smiles>

Scopoletin<smiles>CC(O)CC1Cc2cccc(O)c2C(=O)O1</smiles>

3-(2-Hydroxypropyl)-8-hydroxyl-3,4-dihydroisocoumarin

Figure 3: Structure of coumarins and isocoumarin.

standard (curcumin: $11.2 \mu \mathrm{g} / \mathrm{mL}$ ). Similarly, the $\mathrm{EC}_{50}$ value of the extract for superoxide anion activity was $8.4 \mu \mathrm{g} / \mathrm{mL}$ compared with the standard (ascorbic acid: $12.5 \mu \mathrm{g} / \mathrm{mL}$ ) [53].

In another study to evaluate the DPPH free radical scavenging activity for the methanolic extract of leaves, the extract showed the $\mathrm{IC}_{50}$ values of $45.12 \mu \mathrm{g} / \mathrm{mL}$ as compared to ascorbic acid $(34.91 \mu \mathrm{g} / \mathrm{mL})$. Similarly, in the ferrous ion chelating activity study, the extract had the $\mathrm{IC}_{50}$ value of $64.70 \mu \mathrm{g} / \mathrm{mL}$ as compared to ascorbic acid $(30.96 \mu \mathrm{g} / \mathrm{mL})$ [56].

The DPPH and $\mathrm{ABTS}^{+}$scavenging assay were performed to determine the antioxidant potential of leaves of C. spinosa [40]. The $\mathrm{IC}_{50}$ value recorded was $0.154 \pm 0.14$ and $0.175 \pm 0.12 \mathrm{mg} / \mathrm{mL}$, respectively. Another study recorded the $\mathrm{IC}_{50}$ value of stem and leaves of C. spinosa as 8.08 and $5.35 \mathrm{mg} / \mathrm{mL}$, respectively, as compared to the $\mathrm{IC}_{50}$ value of ascorbic acid $(<2 \mathrm{mg} / \mathrm{mL})$ [39].

All these antioxidant activity evaluation studies were based on the in vitro analysis. The in vivo antioxidant properties and their mechanism of action are yet to be studied.

5.4. Anti-Inflammatory Activities. Anti-inflammatory activities of $C$. spinosa were studied in the carrageenan-induced inflammation test in the hind paw of rats. The inflammation was inhibited by $31.69,35.11$, and $41.62 \%$ at 1 , 3 , and $5 \mathrm{~h}$, respectively, by $200 \mathrm{mg} / \mathrm{kg}$ of a dose of ethanolic extract of leaves of C. spinosa, which was comparable to the inhibition of standard drug indomethacin $(10 \mathrm{mg} / \mathrm{kg})$ [57]. 


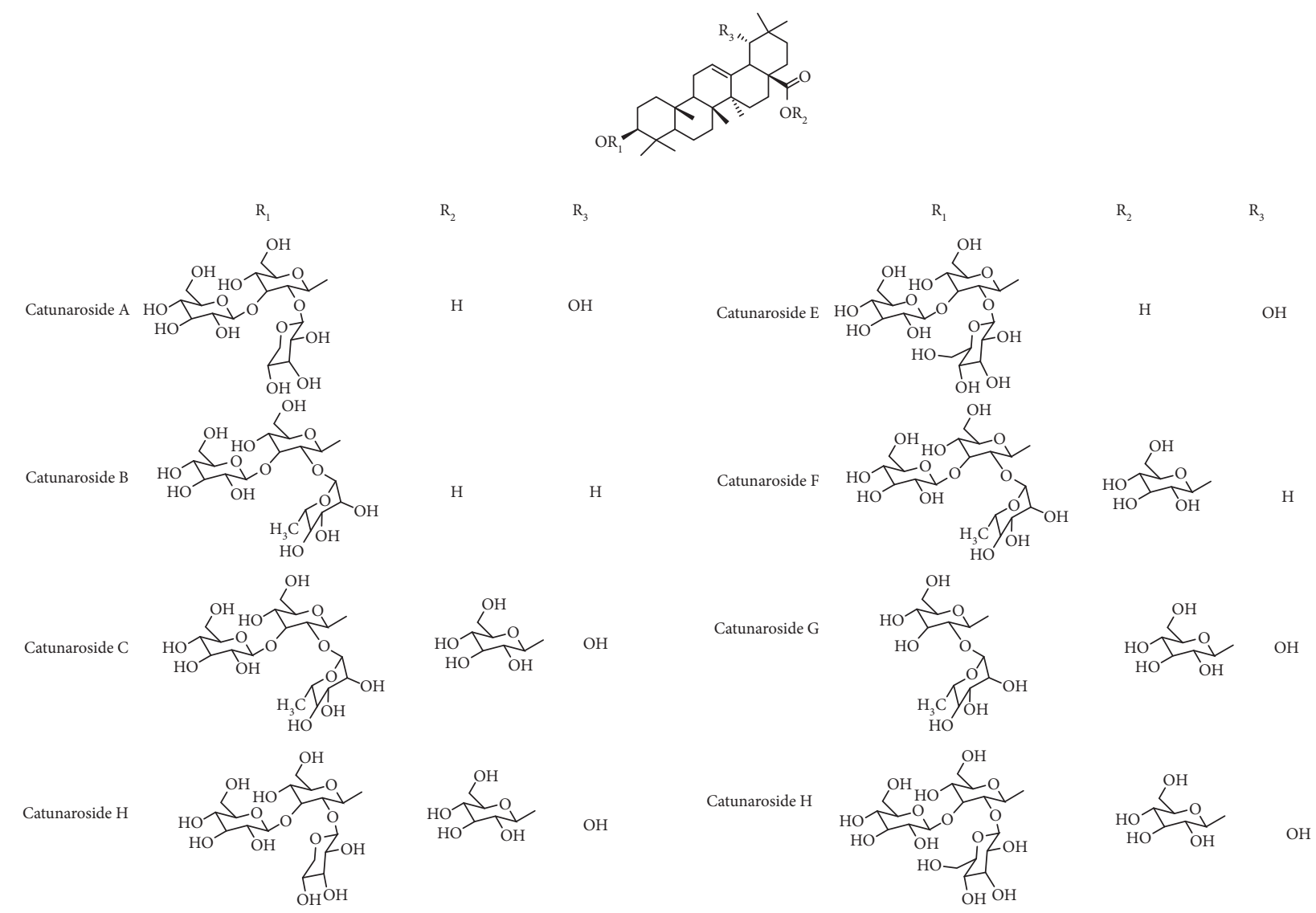

FIgURE 4: Structures of catunarosides A-H.
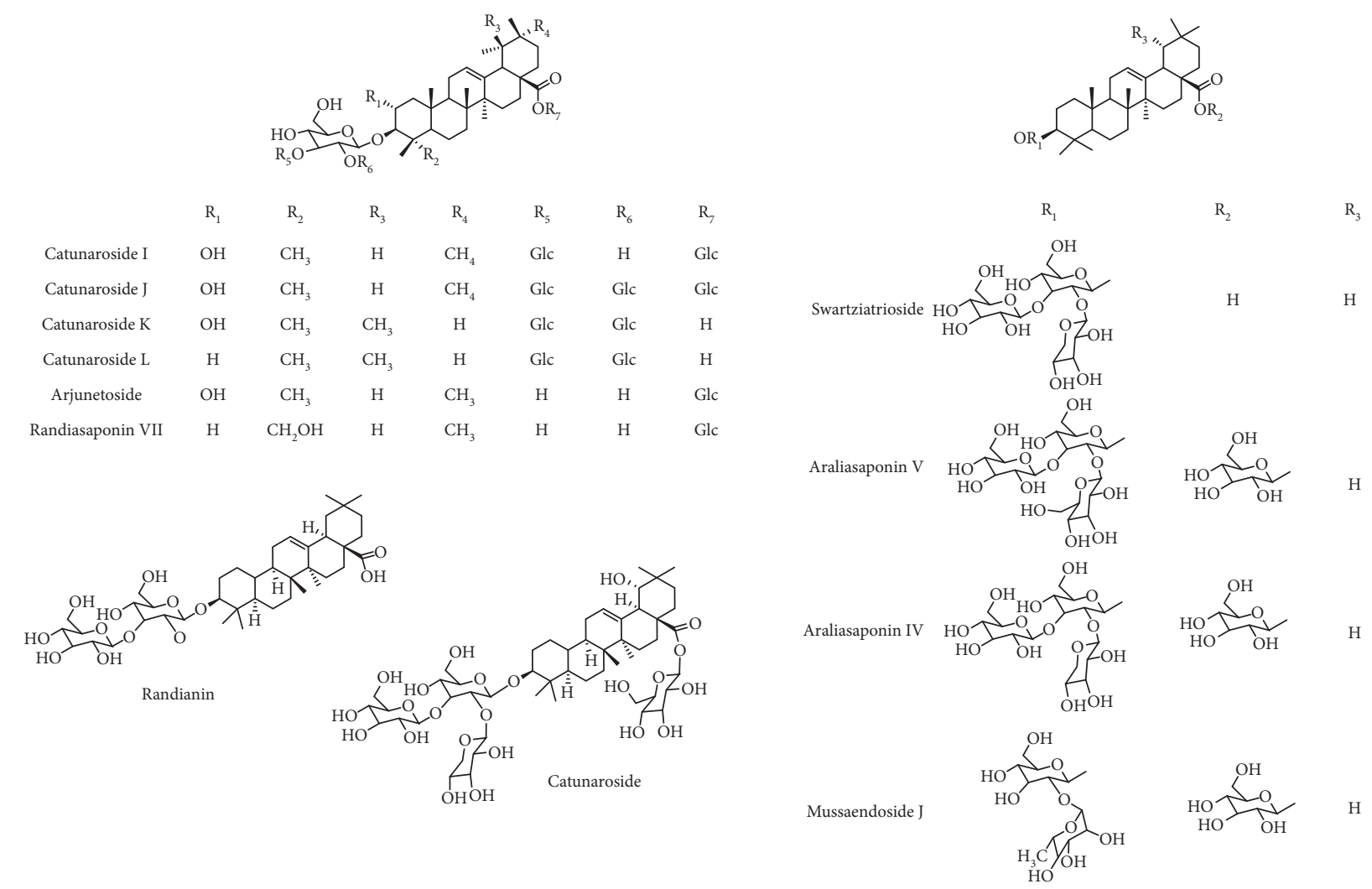

Figure 5: Structures of catunarosides I-L and other saponins. 
<smiles>CC1(C)CC[C@]2(C(=O)O)CC[C@]3(C)C(=CC[C@H]4[C@@]3(C)CC[C@@]3(C)C(C)(C)[C@@H](O)CC[C@]43C)[C@H]2C1</smiles>

Olenolic acid

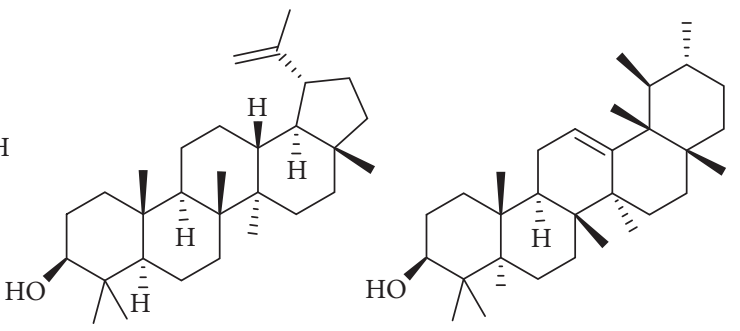

Lupeol

$\alpha$-Amyrin<smiles>CC[C@H](CC[C@H](C)C1CCC2[C@@]1(C)CCC1[C@@]2(C)CC=C2C[C@@H](O)CC[C@@]21C)C(C)C</smiles>
$\beta$-Sitosterol

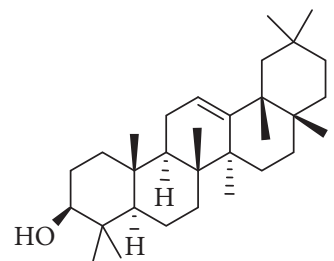

$\beta$-Amyrin<smiles>CC1(C)CC[C@]2(C(=O)O)CC[C@H]3C(=CC[C@H]4[C@@]3(C)CC[C@H]3C(C)(C)[C@@H](O)CC[C@]43C)[C@H]2[C@@H]1O</smiles><smiles>CC(C)[C@@H](C)CC[C@@H](C)C1CCC2[C@@]1(C)CCC1[C@@]2(C)CC=C2C[C@@H](Cl)CC[C@@]21C</smiles>

3b,23-Dihydroxy-olean-12-ene-28-oic acid<smiles>CC1=C2C3=CC[C@@H]4[C@](C)(CC[C@@]5(C)[C@H](C)[C@@H](O)CC[C@]45C)[C@]3(C)CC[C@]2(C(=O)O)CC[C@@H]1C</smiles>

Randialic acid B<smiles>O=C1OCC[C@H]2CC=C(CO)[C@H]12</smiles>

Morindolide<smiles></smiles>

11-Methylioxoside<smiles>O[C@H]1C=C[C@@H]2CCO[C@@H]3OCC[C@@H]1[C@@H]23</smiles>

3-Deoxyartselaenin C

Figure 6: Structures of steroids, terpenoids, and other compounds.

5.5. Antihyperglycemic Activities. Antihyperglycemic activities of methanolic extract of $C$. spinosa fruit extract were studied in the streptozotocin-induced male Wistar diabetic rats. The group of rats treated with standard drug gliclazide and C. spinosa fruit extract showed a decreased level of glucose as compared to the diabetic control group. The value of blood sugar decreased from $88.5 \pm 6.86$ to $74.16 \pm 4.02$ in gliclazide $(50 \mathrm{mg} / \mathrm{kg})$ treated group in between 60 and $120 \mathrm{~min}$, while C. spinosa fruit extract $(400 \mathrm{mg} / \mathrm{kg})$ decreased the blood sugar level from $106.16 \pm 7.8$ to $87.5 \pm 5.00 \mathrm{mg} / \mathrm{dL}$ [24]. The detailed biochemical mechanism by which it acts against hyperglycemia is yet to be studied. The study of isolation of bioactive compounds which can act as hypoglycemic activity from C. spinosa and their characterization can lead to the development of potential drugs in the future.

5.6. Wound Healing Activities. The wound healing was performed in the HUVECs cell and it was treated with catunaregin obtained from the plant $C$. spinosa at concentrations of 10,50 , and $100 \mu \mathrm{M}$ and found to be significant for preventing cell migration. A maximum decrease of $65.4 \%$ in cell migration was recorded for $100 \mu \mathrm{M}$. The next invasion assay was done to demonstrate the antiangiogenesis activity. In this assay, catunaregin significantly decreased the invasion of HUVECs induced by VEGF. The highest decrease of the invasion of HUVECs (61.3\%) was recorded for the concentration of $100 \mu \mathrm{M}$ [31].

5.7. Anticataleptic Activities. The anticataleptic efficiency of the ethanolic extract of fruits of C. spinosa was determined in the catalepsy in mice induced by clonidine and haloperidol. In this study, the forepaw of mice was placed in the bar and the time required to remove the paw from the bar was recorded. The catalepsy recorded for clonidine was $229.2 \pm 14.88 \mathrm{sec}$., which was significantly decreased to $135.2 \pm 4.84$ seconds when treated with $720 \mathrm{mg} / \mathrm{kg}$ of ethanolic extract of fruits of C. spinosa similar to that of standard chlorpheniramine maleate [58].

5.8. Other Activities. The anthelmintic activity of the fruit extract of C. spinosa was studied in Pheretima posthuma. The extract of C. spinosa $(200 \mathrm{mg} / \mathrm{mL})$ was tested against worms for its ability to paralyze and kill the worms. The study showed that the ethanolic extract revels comparable results similar to albendazole $(10 \mathrm{mg} / \mathrm{mL})$, a standard drug as a positive control [59].

There are several other ethnomedicinal practices of C. spinosa such as treating ulcers, asthma, abortifacient, 
curing piles, jaundice, and others on which no pharmacological studies have been made. Further, research can be done on the wide range of pharmaceutical activities related to its ethnomedicinal value.

\section{Toxicological Aspects}

Acute toxicity study showed that the aqueous and alcoholic extracts of C. spinosa at a dose of $2000 \mathrm{mg} / \mathrm{kg}$ in a Swiss albino mice model were found to be nonlethal [14]. Another study regarding the toxicity of 11-methylioxoside obtained from the bark of $C$. spinosa was reported by Jangwan et al. [46]. Upon administrating the single dose of $5000 \mathrm{mg} / \mathrm{kg}$ extract of C. spinosa in Wistar albino rats, no mortality was observed. However, when administrating the different doses of $200 \mathrm{mg} / \mathrm{kg}, 2000 \mathrm{mg} / \mathrm{kg}$, and $5000 \mathrm{mg} / \mathrm{kg}$ continuously up to 14 days, the mortality observed was $0 \%, 25 \%$, and $50 \%$, respectively. The result was supported by a change in biochemical parameters and histopathology reports [60].

Brine shrimp lethality assay was done to study the cytotoxic activities of $C$. spinosa leaf extract and lethal concentration $\left(\mathrm{LC}_{50}\right)$ was determined. The $\mathrm{LC}_{50}$ values of water and ethanol extract were 0.94 and $0.23 \mu \mathrm{g} / \mathrm{ml}$, respectively [12]. A similar study was done in the methanolic extract of the stem and the $\mathrm{LC}_{50}$ value was found to be $1.32 \mu \mathrm{g} / \mathrm{mL}$ [29].

\section{Conclusion and Future Prospects}

C. spinosa is reported to be used in traditional medicine as well as in dietary regimens. Almost all parts of the plant have been used in traditional medicines such as leaves, fruits, stem, stem bark, fruit bark, and root bark. Fruits are also used in food. Various classes of compounds such as polyphenols, flavonoids, terpenoids, triterpenoids, and saponins are reported to be the main constituents found in this plant. The diverse pharmacological activities such as anti-inflammatory, antimicrobial, antidiabetic, antioxidant, and hepatoprotective activities have been investigated with promising results. Despite those promising results, many studies are based only on the in vitro models, and mechanisms of action are not well studied. Some of the research lacked the proper use of positive and negative control in the experiment setting. The in vivo studies were performed with very high doses of extracts and seem practically less efficient. Some ethnopharmacological reports show that this plant has been used to treat ulcer symptoms and acidity; however, pharmacological activities were not performed to evaluate these activities. Future research work must correlate the traditional knowledge with the isolation of active constituents and corresponding pharmacological significance. Along with this, the details of toxicological activities if studied can pave the way to develop new therapeutic agents.

\section{Abbreviations}

ALT: $\quad$ Alanine aminotransferase

AST: Aspartate aminotransferase

DB: $\quad$ Direct bilirubin

DPPH: $\quad$ 1,1-Diphenyl-2-picrylhydrazyl
$\mathrm{HbA}_{1} \mathrm{C}: \quad$ Glycosylated hemoglobin

HUVECs: Human umbilical vein endothelium cells

$\mathrm{IC}_{50}$ : Inhibition concentration $50 \%$

$\mathrm{LC}_{50}$ : Lethal concentration $50 \%$

MIC: $\quad$ Minimum inhibitory concentration

TB: $\quad$ Total bilirubin

TG: $\quad$ Triglyceride

ZOI: Zone of inhibition.

\section{Data Availability}

Data sharing is not applicable. No new data were generated.

\section{Conflicts of Interest}

The authors declare no potential conflicts of interest.

\section{Authors' Contributions}

DT conceived the idea and prepared the first draft of the manuscript. DB and KRS contributed to the literature survey. HPD contributed to the preparation of the first draft and revised the manuscript. All authors read and approved the final version of the manuscript before submission.

\section{References}

[1] N. Sharma and K. Raj Sharma, "Estimation of phenolic content, flavonoid content, antioxidant, and alpha-amylase inhibitory activity of some selected plants from Siraha District Nepal," Asian Journal of Pharmaceutical and Clinical Research, vol. 34, pp. 18-23, 2020.

[2] A. G. Atanasov, B. Waltenberger, E.-M. Pferschy-Wenzig et al., "Discovery and resupply of pharmacologically active plant-derived natural products: a review," Biotechnology Advances, vol. 33, no. 8, pp. 1582-1614, 2015.

[3] B. Allkin, “"Useful plants - medicines: at least 28,187 plant species are currently recorded as being of medicinal use," in State of the World's Plants 2017, K. J. Willis, Ed., Royal Botanic Gardens, London, UK, 2017.

[4] M. Heinrich, G. Appendino, T. Efferth et al., "Best practice in research - overcoming common challenges in phytopharmacological research," Journal of Ethnopharmacology, vol. 246, Article ID 112230, 2020.

[5] A. I. Dirar, A. Adhikari-Devkota, R. M. Kunwar et al., "Genus Blepharis (Acanthaceae): a review of ethnomedicinally used species, and their phytochemistry and pharmacological activities," Journal of Ethnopharmacology, vol. 265, Article ID 113255, 2021.

[6] "Catunaregam spinosa-the plant list," 2020, http://www. theplantlist.org/1.1/browse/A/Rubiaceae/Catunaregam/.

[7] G. Patel Ritesh, L. Pathak Nimish, D. Rathod Jaimik, P. LD, and M. Bhatt Nayna, "Phytopharmacological properties of Randia dumetorum as a potential medicinal tree: an overview," Journal of Applied Pharmaceutical Science, vol. 1, no. 10, 2011.

[8] M. J. Patil, A. R. Bafna, K. Bodas, and S. Shafi, "In vitro antioxidant activity of fruits of randia dumetorum lamk," Journal of Global Trends in Pharmaceutical Sciences, vol. 4, no. 5, pp. 2103-2107, 2014.

[9] A. K. Garg and P. Chouhan, "Madanaphala (randia dumetorum): a pharmacological and pharmacognostical review," 
International Journal of Recent Scientific Research, vol. 10, no. 4, pp. 32061-32064, 2019.

[10] T. D. Prakash, "Madanaphala (Randia dumetorum lam.): a phyto-pharmacological review," International Journal of Ayurvedic Medicine, vol. 6, pp. 74-82, 2015.

[11] Km. Nadkarni and A. K. Nadkarni, "Indian materia medica," Popular Prakashan Pvt Ltd Bombay, vol. 1, p. 799, 1976.

[12] Abdullah-Al-Ragib, T. H. Md, H. Javed, and J. Md, "Antioxidant potential and cytotoxicity of Randia dumetorum Lam. leaf extract," Journal of Pharmacognosy and Phytotherapy, vol. 9, no. 9, pp. 138-145, 2017.

[13] G. Gao, S Qi, S Zhang et al., "Minor compounds from the stem bark of Chinese mangrove associate Catunaregam spinosa," Die Pharmazie, vol. 63, no. 7, pp. 542-544, 2008.

[14] V. Madhavan, B. Vedavathi, A. Raju, A. Murali, and S. Yoganarasimhan, "Sedative activity studies on the aqueous and alcohol extracts of the stem bark of Madanaphala-an ayurvedic drug (Catunaregam spinosa (Thunberg) Tiruvengadam)," Asian Journal of Traditional Medicines, vol. 6, pp. 203-210, 2011.

[15] S. P. Balasubramani, P. Venkatasubramanian, S. K. Kukkupuni, and B. Patwardhan, "Plant-based Rasayana drugs from Ayurveda," Chinese Journal of Integrative Medicine, vol. 17, no. 2, pp. 88-94, 2011.

[16] S. Patel and S. Bhatted, "A comparative study on vamana karma with madanaphala and krutavedhana in ekakushtha (psoriasis)," AYU (An International Quarterly Journal of Research in Ayurveda), vol. 32, no. 4, p. 487, 2011.

[17] R. Kandimalla, S. Kalita, B. Saikia et al., "Antioxidant and hepatoprotective potentiality of Randia dumetorum Lam. Leaf and bark via inhibition of oxidative stress and inflammatory cytokines," Frontiers in Pharmacology, vol. 7, p. 205, 2016.

[18] M. A. Dubois, S. Benze, and H. Wagner, "New biologically active triterpene-saponins from Randia dumetorum," Planta Medica, vol. 56, no. 5, pp. 451-5, 1990.

[19] Y. L. N. Murty, M. A. Jairaj, and A. Sree, “Triterpenoids from randia dumetorum," Phytochemistry, vol. 28, no. 1, 1989.

[20] S. Sotheeswaran, M. Bokel, and W. Kraus, "A hemolytic saponin, randianin, from Randia dumetorum," Phytochemistry, vol. 28 , no. $5,1989$.

[21] O. P. Sati, D. C. Chaukiyal, M. Nishi, K. Miyahara, and T. Kawasaki, "An iridoid from Randia dumetorum," Phytochemistry, vol. 2511 pages, 1986.

[22] A. T. Kulakkattolickal, "Piscicidal plants of Nepal: ripe fruit of Catunaregam spinosa (Thunb.) (Rubiaceae) and leaves of Polygonum hydropiper L. (Polygonaceae) as fish poisons," Aquaculture, vol. 78, no. 3, pp. 293-301, 1989.

[23] O. Sati, D. Chaukiyal, and U. Rana, "Molluscicidal saponins of xeromphis spinosa," Planta Medica, vol. 52, no. 05, pp. 381-383, 1986.

[24] P. R. Mishra, P. K. Panda, K. A. Chowdary, and S. Panigrahi, "Antidiabetic and antihypelipidaemic activity of randia dumetorum," International Journal of Research in Pharmacy and Chemistry, vol. 2, no. 3, 2012.

[25] R. N. Chopra, Glossary of Indian Medicinal Plants, Council of Scientific \& Industrial Research, New Delhi, India, 1956.

[26] S. S. Agarwal and V. K. Singh, "Immunomodulators: a review of studies on Indian medicinal plants and synthetic peptides. Part - I: medicinal plants," Proceedings of the Indian National Science Academy Part B Biological Sciences, vol. B65, no. 3-4, 1999.

[27] J. C. Geesin, J. S. Gordon, and R. A. Berg, "Retinoids affect collagen synthesis through inhibition of ascorbate-induced lipid peroxidation in cultured human dermal fibroblasts," Archives of Biochemistry and Biophysics, vol. 278, no. 2, pp. 350-355, 1990.

[28] A. K. Garg, A. Singh, H. Vishnoi, G. C. Meena, C. Singh, and M. Adlakha, "Swine flu- the changing scenario and preparedness with formulation of win flu air freshener gel," International Journal of Ayurveda and Pharma Research, vol. 5, no. 11, pp. 14-20, 2017.

[29] M. Hassan and Abdullah-Al-Ragib, "Tanvir hossain, sazaul morshed sazib, and muhammad zukaul islam, "evaluation of antioxidant activity and brine shrimp lethality bioassay of randia dumetorum stem extract," North American Academy Research, vol. 3, no. 1, pp. 1-14, 2020.

[30] M. A. H. Mollik, M. S. Hossan, A. K. Paul, M. Taufiq-UrRahman, R. Jahan, and M. Rahmatullah, "A comparative analysis of medicinal plants used by folk medicinal healers in three districts of Bangladesh and inquiry as to mode of selection of medicinal plants," Ethnobotany Research and Applications, vol. 8, 2010.

[31] J.-X. Liu, M.-Q. Luo, M. Xia et al., "Marine compound catunaregin inhibits angiogenesis through the modulation of phosphorylation of akt and eNOS in vivo and in vitro," Marine Drugs, vol. 12, no. 5, pp. 2790-2801, 2014.

[32] S. K. Bhattacharya, A. Bhattacharya, and A. Chakrabarti, "Adaptogenic activity of Siotone, a polyherbal formulation of ayurvedic rasayanas," Indian Journal of Experimental Biology, vol. 38, pp. 119-128, 2000.

[33] M. Varadharajan, Y. Sunkam, G. Magadi, D. Rajamanickam, D. Reddy, and V. Bankapura, "Pharmacognostical studies on the root bark and stem bark of Catunaregam spinosa (Thunb.) Tiruv. (Madanaphala) - an Ayurvedic drug," Spatula DD Peer Reviewed Journal on Complementary Medicine and Drug Discovery, vol. 4, no. 2, pp. 89-99, 2014.

[34] P. Bhat, G. R. Hegde, G. Hegde, and G. S. Mulgund, "Ethnomedicinal plants to cure skin diseases-an account of the traditional knowledge in the coastal parts of Central Western Ghats, Karnataka, India," Journal of Ethnopharmacology, vol. 151, no. 1, pp. 493-502, 2014.

[35] Z. A. Malik, J. A. Bhat, R. Ballabha, R. W. Bussmann, and A. B. Bhatt, "Ethnomedicinal plants traditionally used in health care practices by inhabitants of Western Himalaya," Journal of Ethnopharmacology, vol. 172, pp. 133-144, 2015.

[36] A. N. Anoopkumar, S. Rebello, A. V. Sudhikumar, S. Puthur, and E. M. Aneesh, "A novel intervention on the inhibiting effects of Catunaregam spinosa induced free radical formation and DNA damage in Aedes aegypti (Diptera: Culicidae): a verdict for new perspectives on microorganism targeted vector control approach," International Journal of Tropical Insect Science, vol. 40, no. 4, pp. 989-1002, 2020.

[37] S. P. Anand, S. Deborah, and G. Velmurugan, "Evaluation of antioxidant activity of some wild edible fruits collected from Boda and Kolli hills," The Journal of Phytopharmacology, vol. 72, pp. 127-133, 2018.

[38] R. Senthamarai, T. S. V. Kirubha, and S. Gayathri, "Pharmacognostical and phytochemical studies on fruits of Catunaregam spinosa Linn," Journal of Chemical and Pharmaceutical Research, vol. 3, no. 6, pp. 829-838, 2011.

[39] S. Damle and K. Sharon, "Antioxidant activity, TLC and HPLC-ESI-Q-TOF-MS fingerprinting of Catunaregam spinosa (Thunb.) triveng," Journal of Pharmacognosy and Phytochemistry, vol. 4, pp. 2119-2124, 2018.

[40] S. Shailasree, K. K. Sampathkumara, S. R. Niranjana, and H. S. Prakash, "Bioactive potential of medicinal plants from 
western ghats region, India," Journal of Herbs, Spices, \& Medicinal Plants, vol. 20, no. 3, pp. 221-234, 2014.

[41] D. T. Ekanayake, "Plants used in the treatment of skeletal fractures in the indigeneous system of medicine in Sri Lanka," Srilanka Foreign Journal, vol. 14, pp. 145-152, 1980.

[42] L. Hamerski, M. Furlan, D. H. Siqueira Silva et al., "Iridoid glucosides from randia spinosa (Rubiaceae)," Phytochemistry, vol. 63, no. 4, pp. 397-400, 2003.

[43] K. D. Yang, Y. J. Li, L. Ge, and Z. Z. Qin, "Isolation of triterpenoids from catunaregam spinosa," Advanced Materials Research, vol. 236, pp. 1731-1737, 2011.

[44] G.-C. Gao, X.-M. Wei, S.-H. Qi, H. Yin, Z.-H. Xiao, and S. Zhang, "Catunaregin and epicatunaregin, two norneolignans possessing an unprecedented skeleton fromcatunaregam spinosa," Helvetica Chimica Acta, vol. 93, no. 2, pp. 339-344, 2010.

[45] J. Li, X. Huang, X.-H. Jiang et al., "Catunarosides I-L, four new triterpenoid saponins from the stem bark of catunaregam spinosa," Chemical and Pharmaceutical Bulletin, vol. 63, no. 5, pp. 388-392, 2015.

[46] J. S. Jangwan, R. P. Aquino, T. Mencherini, and R. Singh, "Isolation and in vitro cytotoxic activity of 11-methylixoside isolated from bark of Randia dumetorum Lamk," Herba Polonica, vol. 59, no. 1, 2013.

[47] J. S. Jangwan, R. Aquino, T. Mencherini, and R. Singh, "Chemical investigation and in vitro cytotoxic activity of Randia dumetorum lamk bark," International Journal of Chemical Sciences, vol. 10, pp. 1374-1382, 2012.

[48] G. Gao, Z. Lu, S. Tao, S. Zhang, and F. Wang, "Triterpenoid saponins with antifeedant activities from stem bark of Catunaregam spinosa (Rubiaceae) against Plutella xylostella (Plutellidae)," Carbohydrate Research, vol. 346, no. 14, pp. 2200-2205, 2011.

[49] G.-C. Gao, Z.-X. Lu, S.-H. Tao, S. Zhang, F.-Z. Wang, and Q.-X. Li, "Triterpenoid saponins from the stem bark of Catunaregam spinosa," Canadian Journal of Chemistry, vol. 89, no. 10, pp. 1277-1282, 2011.

[50] M. Raza, "Isolation and chromatographic finger printing of randialic acid B an abortifacient agent isolated from bark of ayurvedic medicinal plant Randia spinosa(poir.) Rubiaceae," Asian Journal of Pharmaceutical Analysis and Medicinal Chemistry, vol. 4, pp. 107-111, 2016.

[51] M. Dharmishtha, S. H. Mishra, and G. Falguni, "Development and validation of HPTLC method for quantitative estimation of oleanolic acid as marker in total methanolic extract of fruits of Randia dumetorum lamk," Pharmacognosy Magazine, vol. 520 pages, 2009.

[52] G. S. Saharia and V. Seshadri, "Chemical investigation on Randia saponins, isolation and characterisation of randioside A," Indian Journal of Forestry, vol. 3, no. 1, pp. 6-8, 1980.

[53] K. A. Parmar, S. N. Prajapati, and A. P. Jani, "Phytochemical screening of Randia dumetoram plant extracts for the antioxidant activity by DPPH method and their antibacterial and antiviral activities," International Journal of Chemical Sciences, vol. 8, no. 2, pp. 1101-1109, 2010.

[54] S. P. Anand, S. Deborah, and G. Velmurugan, "Antimicrobial activity, nutritional profile and phytochemical screening of wild edible fruit of catunaregam spinosa (Thunb.) triveng," The Pharma Innovation, vol. 6, no. 10, pp. 106-109, 2017.

[55] A. A. Noorani and M. K. Kale, "Pretreatment of albino rats with methanolic fruit extract of Randia Dumetorum (L.) protects against alcohol induced liver damage," Korean Journal of Physiology and Pharmacology: Official Journal of the
Korean Physiological Society and the Korean Society of Pharmacology, vol. 16, no. 2, pp. 125-30, 2012.

[56] G. Gandhimathi and G. V. S. Bai, "In vitro antioxidant activity of Randia dumetorum Lam leaf extract," International Journal of Herbal Medicine, vol. 1, pp. 107-111, 2013.

[57] H. Saini, J. Dwivedi, H. Paliwal, U. Kataria, P. Chauhan, and R. Garg, "Anti-inflammatory, analgesic and antipyretic activity of catunaregam spinosa (Thumb.) tirveng extracts," Journal of Drug Delivery and Therapeutics, vol. 5, no. 5, pp. 89-94, 2019.

[58] M. M. Ghaisas, P. B. Ninave, G. P. Ganu, V. S. Zope, M. B. Tanwar, and A. D. Deshpande, "Effect of Randia dumetorum Lam on clonidine and haloperidol-induced catalepsy in mice," Pharmacologyonline, vol. 2, pp. 42-50, 2008.

[59] B. Jyothirmayi, L. Tejaswini, G. A. Latha, C. Swathi, G. Nishitha, and R. Unissa, "Anthelmintic evaluation of Randia dumetorum fruit extracts," Journal of Pharmacy Research, vol. 54, pp. 880-883, 2018.

[60] P. B. Ninave, M. M. Ghaisas, M. D. Lande, V. S. Zope, M. B. Tanwar, and A. D. Deshpande, "Anti-histaminic and anti-anaphylactic activity of randia dumetorum," Pharamacologyonline, vol. 2, pp. 322-330, 2011. 